\title{
CIENTIFICA
}

\section{Willoughby, Gullick e seus Críticos}

\section{Tomás de Vilanova Monteiro Lopes}

$\mathrm{D}$

ENTRE os teóricos da administração pública nestes últimos quarenta anos, dois conseguiram dar ao seu pensamento grande ressonância. Foram êles Willoughby e Luther Gullick.

O primeiro num livro publicado em 1927 ("Principles of Public Administration") definiu sua posição em relação à matéria neste trecho bastante expressivo:

"A posição aqui assumida é a de que há, em administração, certos princípios fundamentais de aplicação geral, análogos aos que caracterizam qualquer ciência, os quais devem ser observados para que o fim da administração, a eficiência, seja antingida, e a de que os aludidos princípios devem ser estabelecidos e seu significado definido sòmente pela rigida aplicação do método científico de investigação".

Tal posição nos parece correta e atual, porque, restrição feita à menção da eficiência como fim da administração, o que os modernos teóricos buscam não é, senão, certos elementos que pela sua universalidade permitam conceber a administração em têrmos que não dependam das circunstâncias de tempo, lugar e cultura. $\mathrm{E}^{\prime}$ possivel que êsses elementos, tão afanosamente procurados hoje, não coincidam com os princípios formulados por Willoughby.

Mas, por acaso, isso justificará a severidade das críticas de que têm sido alvo os "Princípios"?

O que Willoughby preconizava, e nisso está, a nosso ver, a dimensão mais importante de sua obra, era uma atitude cientifica no estudo da administração e a formulação de umas tantas proposições às quais se pudesse chegar pela rígida aplicação do método científico.

Os "princípios", que um dos seus críticos (Herbert A. Simon) reduziu à categoria de provérbios, foram deduzidos num estágio em que a experiência e os conhecimentos humanos sôbre o fenô- 
meno extremamente complexo que é a administração, estavam ainda muito longe de ser o que hoje são. Decerto não se poderia pretender que êles permanecessem a cavaleiro da evolução do pensamento humano.

O êrro fundamental dos críticos de Willoughby provém do fato de haverem êles se apegado demasiadamente aos "principios", esquecendo a posição do velho mestre, a qual permaneceu invariável e é a mesma em que se colocam os referidos criticos. Estes, como Willoughby, também desejam (mas ainda não puderam, apesar de contarem com melhores subsídios) extrair da citada posição os critérios universais com que tanto têm sonhado.

Traduzimos, há tempos, para a Revista do Serviço Público (dezembro de 1951), um artigo de Roscoe Martin, no qual, entre outras cousas, consta a afirmação de que

"é de admirar e talvez mesmo de alarmar que o livro de Willoughby ainda hoje seja extensamente considerado e por pessoas de influência como uma obra "básica e corrente". (O grifo é do original).

Não sabemos até que ponto os estudiosos da administração consideram, efetivamente, o livro de Willoughby como uma obra "corrente", mas não vemos por que não a possam considerar uma obra básica, desde que se tome êste qualificativo com o sentido de pioneira ou de representativa de uma corrente de opinião que exerceu e continua exercendo considerável influxo no estudo da administração.

Quando examinamos a obra dos modernos teóricos da administração, chegamos a ter dúvida de que êles, realmente, repudiam a idéia da eficiência como finalidade da administração. Não estará o repúdio a essa idéia mais nas palavras do que nas implicações finais das teorias?

A "tomada de decisões", o "equilibrio dinâmico", a "racionalidade e a irracionalidade" de que hoje tanto se fala serão, acaso, um fim em si mesmos? ou serão, apenas, meios através dos quais buscamos alguma cousa que a "eficiência" - vocábulo tão útil e tão adaptável a uma infinidade de objetivos - pode exprimir?

Roscoe Martin, no artigo ao qual já tivemos ensejo de aludir, após censurar Willoughby por haver apontado a eficiência como finalidade da administração pública, define esta última, dizendo que ela

"é o que ocorre quando um grupo, grande ou pequeno, coopera na realização de um objetivo público em tôrno do qual todos estão de acôrdo. $\mathrm{O}$ acôrdo quanto ao 
fim não constitui essencialmente a administração; esta se traduz na ação do grupo, visando ao aludido fim. O cerne do problema da administração reside no adequado ordenamento dos esforços do grupo para a conquista do resultado desejado".

Que encerram, afinal, essas palavras senão a idéia que Roscoe Martin combate em Willoughby? A conquista do "resultado desejado", "mediante o adequado ordenamento dos esforços do grupo" que nome tem? Acaso não ẻ eficiência? Que é que leva o administrador a tomar uma decisão? a buscar o equilibrio dinâmico ou a satisfazer as forças das quais depende a sua sobrevivência como chefe, ou a sobrevivência da organização? Não haverá, em tôdas essas hipóteses, um objetivo, sem o qual a atividade administrativa se desenvolveria no vácuo? E se êsse objetivo pode ser alcançado inteira ou parcialmente, não nos é lícito pretender que a administração o alcance da melhor maneira possivel? Acaso não foi para essa correspondência entre objetivos, meios e resultados que se cunhou o vocábulo eficiência?

Herbert Simon parece que não recusaria legitimidade a essas conclusões. Pelo menos escreveu êle no seu conhecido artigo "Os Provérbios da Administração" que

"no projeto das organizaçóes administrativas, bem como em suas operacões, o critério de orientação deve ser a eficiência geral".

Ou ainda, que

"na realidade, o "princípio da eficiência" deveria ser considerado mais uma definição do que um principio; a definição do que se entende por "boa" ou "correta" atitude administrativa". Êle não diz como as realizações podem atingir ao máximo, mas apenas estatui que ôste máximo é o objetivo da atividade administrativa, e que a teoria administrativa deve revelar quais as condições necessárias para que tal máximo seja atingido".

A crítica de Herbert Simon à obra de Willoughby aproxima-se da de Roscoe Martin, nảo apenas porque se dirigem ambas ao mesmo alvo, mas porque os dois autores se lançam à demolição daquela obra sem oferecer algo que pudesse realmente substituíla. Demoliu-se o velho prédio, deixando-se os moradores ao relento, pela incapacidade de construir um prédio melhor.

Sôbre os entulhos da demolição, Roscoe Martin esparziu alguns conceitos de valor muito discutivel, como, por exemplo, o de 
administração pública, reproduzido numa passagem dêstes comentários; Herbert Simon empilhou alguns materiais, especificando de maneira assaz deficiente o uso que dêles poderiamos fazer. Com os materiais que nos dá e as especificaçôes que nos apresenta não podemos sequer construir uma instalação provisória para abrigar os moradores do prédio demolido.

Parece-nos que os modernos teóricos da administração têm tomado caminhos que, ao invés de os aproximarem dos objetivos colimados, cada vez mais os distanciam dēsses objetivos. No fenômeno a estudar, êles encaram aspectos cada vez mais limitados, - que os faz ir perdendo, progressivamente, a visão de conjunto da administração. Por outro lado, nem sempre os aspectos estudados podem ser reunidos num todo orgânico, cuja contribuição global, para a formulação de uma teoria administrativa, se afigure suficientemente categórica.

Os tradicionalistas possuíam mais unidade e organicidade de idéias. Uma e outra, considerados os fins práticos da administração, revestem-se de grande valor. Por isso mesmo puderam êles (tradicionalistas) dar aos administradores, além de uma concepção do fenômeno administrativo, alguns instrumentos de trabalho, cuja validade ainda hoje é plenamente reconhecida.

A menos que se possa construir uma teoria administrativa apenas em tôrno de simbolos e abstrações, com desprêzo dos fatos através dos quais o fenômeno administrativo se concretiza, o mérito da obra dos tradicionalistas permanecerá invulnerável à crítica dos pensadores modernos. E tanto isso é verdade que já se prenuncia um retôrno aos "Princípios", em tôrno do qual as divergências de opinião nasceram e se avolumaram.

Não há nada de surpreendente nessa espécie de "recurso histórico". E' fenômeno que sói acontecer quando as águas engrossadas por uma agitação de superfície, retornam, afinal, à sua tranqüilidade. No caso da teoria administrativa a agitação que se estabeleceu em redor da obra dos tradicionalistas foi útil, porque levou ao desenvolvimento de idéias que naquela obra já se continham em caráter embronário e, talvez mal definidas (v. g. a análise do processo de tomada de decisões; o comportamento do indivíduo e dos grupos dentro da organização; e, não obstante, a dubiedade dos conceitos com que atualmente ainda se apresenta, o continuo politica-administração). Todavia, a maior contribuição dos modernos estudos sôbre a teoria administrativa talvez tenha partido da corrente sociológica. A interpretação do fenômeno administrativo como fenômeno social e, portanto, sujeito a uma multiplicidade de fatôres, veio possibil tar à formulação daquela teoria a amplitude de perspectiva que the estava faltando. Isso, naturalmente, implicou em dificuldades novas, dado que, no estado atual dos conhecimentos humanos, não sòmente à ainda fluida sob 
muitos aspectos a distinção entre fenômeno administrativo e outros fenômenos sociais, notadamente, o direito e a politica, senão também porque certos fatôres contingentes e, portanto, pouco propícios à formulação de uma teoria administrativa universalmente válida, terão de ser considerados.

O caminho a percorrer está apenas começando a ser aberto, e prenuncia-se longo e difícil. Acreditamos que o govêrno, forma de positivação mais típica do fenômeno administrativo, virá a desempenhar, em relação à teroia administrativa, o mesmo papel que a lei, forma de positivação mais tipica do fenômeno jurídico, representou em relação à teroia do direito.

Isso quer dizer que o "processus", o "modus faciendi" da administração continuará a constituir uma categoria essencial para a formulação de uma teoria administrativa e, na medida que essa opinião fôr verdadeira, a obra dos tradicionalistas não pode ser posta à margem, e há de servir para qualquer outra cousa mais do que simples alvo de criticas. 